\title{
Dietary inadequacies observed in homeless men visiting an emergency night shelter in Paris
}

\author{
Nicole Darmon ${ }^{1, *}$, J Coupel $^{2}, \mathrm{M} \mathrm{Deheeger}^{1}$ and A Briend ${ }^{1,3}$ \\ ${ }^{1}$ Institut National de la Santé et de la Recherche Médicale/Institut Scientifique et Technique de la Nutrition et de \\ I'Alimentation, 5 rue du Vertbois, 75003 Paris, France: ${ }^{2}$ Association des Cités du Secours Catholique, 17 Bd Ney, \\ 75018 Paris, France: ${ }^{3}$ Institut de Recherche pour le Développement, Paris, France
}

Submitted 19 October 1999: Accepted 6 June 2000

\begin{abstract}
Objective: To assess the dietary intake and the nutritional status of homeless men. Setting: A night emergency shelter in Paris, France.

Design: Dietary survey (48-h) including alcohol intake and a questionnaire on age, duration of homelessness, smoking habits. Subjects were also weighed and measured.

Subjects: Ninety-seven men aged 18-72 years (mean 43.3), of whom 54\% were homeless for more than 18 months, $82 \%$ were smokers and 53\% were regular and/or excessive drinkers.

Results: The BMI distribution was shifted towards low values, the percentage of wasted persons being four times higher than in the reference population. The mean total energy intake was $2376 \mathrm{kcal}(\mathrm{SD}=879)$ and included a high and highly variable percentage of energy derived from alcohol $(12.0 \%(\mathrm{SD}=18.1))$. Among drinkers, the mean ethanol intake was $90 \mathrm{~g}(\mathrm{SD}=102)$ and there was a significant negative correlation between ethanol and non-alcoholic energy intakes. The median intakes of potassium, calcium, zinc, vitamins B1, B2, and niacin were lower than European Population Reference Intakes but only the mean intake of vitamin B1 was significantly lower. Eighty percent of non-alcoholic energy was provided by charitable organisations. For most nutrients, the nutritional density of the shelter ration was not significantly different from the density of the foods purchased by the homeless.

Conclusions: These data suggest that the content of some nutrients should be increased in existing food assistance programs for homeless people in France.
\end{abstract}

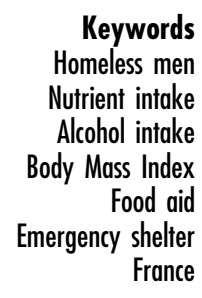

Mortality in homeless people is high ${ }^{1-3}$. Homeless people also have a high morbidity, particularly mental illnesses, physical injuries, liver diseases and infectious diseases ${ }^{4-6}$. Addiction, particularly alcoholism, is a major aggravating factor in determining morbidity ${ }^{7}$ and mortality ${ }^{2}$ among them. A recent study showed that homeless people living in France lack appropriate health care and are more exposed to diseases and accidents than the rest of the population ${ }^{8}$. This may partly be explained by their poor living conditions and by their unwillingness to use health services. The role of inadequate food intake in the increased morbidity and mortality is unknown.

The majority of homeless people are usually willing to take advantage of night shelters and food distributions, or free meals provided by relief organisations. There is some evidence however, that their nutritional status might be inadequate. Anthropometric studies have shown a high prevalence of wasting malnutrition in homeless adults living in the United States ${ }^{9-12}$. Arguably, programmes to limit the nutritional consequences of homelessness should have a beneficial impact on their general health status if their dietary intake is inadequate. Programmes might include adjustment of the composition of meals in night shelter or distribution of highly nutrient dense foods. Yet, design of nutritional programmes for the homeless is limited by a lack of knowledge of their usual dietary intake: little information is available on which nutrients are most likely to be lacking in their diet. We conducted the present study to assess the nutrient intake of homeless men housed in a Parisian shelter.

\section{Methods}

In Paris, programmes for homeless people are coordinated by the SAMU (Service d'Aide Médicale d'Urgence) Social, initially established in 1993 by the City of Paris. 
This organisation assists homeless people to find a bed in an emergency shelter, mainly through a toll-free telephone number (115). These shelters are usually run by independent private charitable organisations having an agreement with the SAMU social. The SAMU social also has minibuses collecting homeless from the street to bring them to these shelters. Homeless people needing medical care are referred by the SAMU to public hospital or day care centres. In emergency shelters, homeless peoples are offered a bed, dinner and breakfast for 3 consecutive days.

In the absence of a better alternative, it was assumed that homeless people presenting themselves at these shelters were representative of the homeless population. This study was conducted between February and August 1999 in one of the most important of these shelters in Paris with a total of 140 beds (Association des Cités du Secours Catholique, $17 \mathrm{Bd}$ Ney, Paris). Men represent more than $80 \%$ of the Paris homeless population ${ }^{13,14}$, and this study was done in an emergency shelter for men.

Once a week, after dinner, three to five subjects were asked to participate in a 20 -min face-to-face interview to assess dietary intake. The refusal rate was low, approximately $10 \%$. The total number of participating subjects was 97 men. Interviews were carried out on different days of the week. They were conducted by a nutritionist (ND), consisted in a brief questionnaire on age, duration of homelessness and smoking habits followed by a 48-h dietary recall. A 48-h recall was chosen to obtain information on dietary intake during the days spent outside the shelter. Assessment of quantity, frequency and type of alcoholic beverages were included in the dietary recall. To minimise recall bias, data were systematically checked with the shelter menus and portions served were regularly weighed in the kitchen. The source of foods and the site of eating were recorded. A previously validated photographic manual ${ }^{15}$ was used to help subjects quantify portion sizes. Body weight, with minimal clothing, and height were also measured. Nutritional status was estimated by the body mass index (BMI, $\mathrm{kg} / \mathrm{m}^{2}$ ). The adequacy of nutritional intake was assessed by calculating the energy and nutrient intakes with a computer programme based on a food composition table with 900 items adapted to the French eating habits ${ }^{16,17}$.

The BMI distribution in our sample was compared with a representative sample of French men of the same age ${ }^{18}$ by using the LMS method to calculate Z-scores ${ }^{19}$. The mean intakes of nutrients were compared with European recommendations (Population Reference Intake values $)^{20}$, which are lower than French ${ }^{21}$ or American ${ }^{22}$ recommendations for all nutrients except potassium.

Statview statistical software (Statview, version 5, Abacus concepts, Inc., Berkeley, California) was used for statistical analysis.

According to French law (Loi Huriet-Sérusclat), this study did not require ethical clearance because interviews were anonymous, no biological sample was collected and no question was asked about ethnic origin or political or religious opinions. General recommendations of the ADELF (Association des Epidémiologistes de Langue Française) for conducting epidemiological studies were followed $^{23}$. In particular, subjects were informed about the kind of data collected, study aim and data exploitation and were told they were free to accept or refuse participating in the study.

\section{Results}

\section{General characteristics of the sample}

The mean age of the subjects was 43.3 years $(\mathrm{SD}=12.5$; range 18-72). Fifty-four percent of the subjects were homeless for more than 18 months. Eighty-two percent were smokers and 53\%, hereafter classified as drinkers, reported either the intake of more than three glasses of alcohol each day and/or the irregular intake of alcohol in excess. There was a significant association between being homeless for more than 18 months and being a drinker: 66\% subjects homeless for more than 18 months were drinkers compared with $40 \%$ among others $(P=0.011)$. Drinkers were significantly older than non-drinkers ( 46.3 $(\mathrm{SD}=10.4)$ vs. $41.2(\mathrm{SD}=13.4)$ years, $P=0.049)$. Subjects who had been homeless for more than 18 months were older than those who had been homeless for less than 18 months $(46.1(\mathrm{SD}=10.8)$ vs. $40.6(\mathrm{SD}=13.4)$ years, $P=0.033)$.

\section{Energy, alcobol and macronutrient intakes (Table 1)} The mean number of meals per day was $2.3(\mathrm{SD}=0.7$; range $1-4)$ and the mean number of snacks 0.75 (SD = 0.98; range $0-5$ ). Only 15 persons had dinner outside the shelter the day before the interview. As there was no significant difference (paired $t$-test) between the energy intake during the day of the interview and the day before, the daily intake was calculated from the 48-h recall. The mean total energy intake was $2376 \mathrm{kcal}(\mathrm{SD}=879)$. This included a high (and highly variable) consumption of ethanol. The mean energy derived from alcohol was $12.0 \%(\mathrm{SD}=18.1)$, which is higher than the $7 \%-8 \%$

Table 1 Energy and macronutrient daily intakes

\begin{tabular}{|c|c|c|c|}
\hline \multicolumn{2}{|l|}{ Nutrient } & \multirow{2}{*}{$\begin{array}{c}\text { Mean (SD) } \\
2376(879) \\
9.93(3.67)\end{array}$} & \multirow{2}{*}{$\begin{array}{c}\text { Median } \\
\begin{array}{r}2364 \\
9.88\end{array}\end{array}$} \\
\hline Total energy & kcal/day & & \\
\hline Non-alcoholic energy & kcal/day & $2032(763)$ & 1930 \\
\hline & MJ/day & 8.49 (3.20) & 8.07 \\
\hline Proteins & g/day & $83.4(30.2)$ & $\begin{array}{l}82.2 \\
16.7\end{array}$ \\
\hline Fat & $\begin{array}{l}\% \text { non } \\
\text { g/day }\end{array}$ & $\begin{array}{l}16.8(3.7) \\
72.6(34)\end{array}$ & $\begin{array}{l}16.7 \\
64.1 \\
316\end{array}$ \\
\hline Carbohydrates & $\begin{array}{l}\% \text { non-alcoholic energy } \\
\text { g/day } \\
\% \text { non-alcoholic energy }\end{array}$ & $\begin{array}{c}31.9(7.7) \\
261(110) \\
51.3(8.6)\end{array}$ & $\begin{array}{l}31.6 \\
250 \\
51.9\end{array}$ \\
\hline Alcohol & $\begin{array}{l}\text { g/day } \\
\% \text { total energy }\end{array}$ & $\begin{array}{l}49.1(85.9) \\
12.0(18.1)\end{array}$ & $\begin{array}{l}3.12 \\
0.8\end{array}$ \\
\hline
\end{tabular}


Table 2 Mineral and vitamin daily intakes

\begin{tabular}{|c|c|c|c|}
\hline Nutrient & Mean (SD) & Median & PRI \\
\hline Potassium (mg) & 2941 (1188) & 2801 & 3100 \\
\hline Calcium (mg) & $721(296)$ & 670 & 700 \\
\hline Phosphorus (mg) & $1182(415)^{*}$ & 1129 & 550 \\
\hline Iron (mg) & $14.6(8.1)^{\star}$ & 13.2 & 9 \\
\hline Magnesium (mg) & $336(166)^{*}$ & 302 & 150 \\
\hline Copper (mg) & $1.72(0.98)^{*}$ & 1.42 & 1.1 \\
\hline Zinc (mg) & $9.50(3.55)$ & 9.23 & 9.5 \\
\hline Vitamin B1 (mg) & $0.93(0.37)^{\star \star}$ & 0.87 & 1.1 \\
\hline Vitamin B2 (mg) & $1.62(1.18)$ & 1.24 & 1.6 \\
\hline Niacin $(\mathrm{mg})$ & $19.0(9.8)$ & 17.6 & 18 \\
\hline Vitamin B6 (mg) & $2.02(1.21)^{*}$ & 1.77 & 1.5 \\
\hline Folate $(\mu \mathrm{g})$ & $259(138)^{\star}$ & 234 & 200 \\
\hline Vitamin B12 $(\mu \mathrm{g})$ & $5.03(5.83)^{*}$ & 3.24 & 1.4 \\
\hline Vitamin A ( $\mu$ g retinol-eq.) & $1028(1135)^{\star}$ & 579 & 700 \\
\hline Vitamin C (mg) & $64.8(52.5)^{\star}$ & 52.7 & 45 \\
\hline Vitamin D $(\mu \mathrm{g})$ & $1.58(2.92)$ & 0.72 & - \\
\hline
\end{tabular}

* Significantly higher than the corresponding PRI value $(P<0.01)$; ${ }^{* *}$ significantly lower than the corresponding PRI value $(P<0.01)$.

observed for men in representative surveys of the French population ${ }^{24,25}$. Non-alcoholic energy intake was low $(2032 \mathrm{kcal}(\mathrm{SD}=763))$, about $200-250 \mathrm{kcal}$ less than reported for the French male population in three recent surveys ${ }^{24-26}$. Of the non-alcoholic energy, $16.8 \%$ came from proteins, $31.9 \%$ came from fat and $51.3 \%$ from carbohydrates. As expected, total energy intake was positively correlated with ethanol intake ( $r=0.52, P<0.0001)$. However, ethanol intake was negatively correlated with non-alcoholic energy intake $(r=-0.19, \quad P=0.067)$ and with lipid intake $(r=$ $-0.22, P=0.033$ ).

Drinkers had a mean intake of ethanol of $90 \mathrm{~g} /$ day $(\mathrm{SD}=102)$, a quantity which is not significantly different from the recently estimated mean ethanol intake (118 $(\mathrm{SD}=81) \mathrm{g} /$ day) of 3346 men hospitalised for severe alcoholism or associated-pathologies in the Parisian $\operatorname{area}^{27}$. Among drinkers, the negative correlation between ethanol intake and non-alcoholic energy intake was significant $(r=-0.30, P=0.030)$, and could be attributed to lower lipid, carbohydrates and protein intakes at higher levels of ethanol consumption.

\section{Mean and median intakes of minerals and vitamins (Table 2)}

The mean intakes of phosphorus, iron, copper, magnesium, folate, vitamins B6, B12, A and C significantly exceeded the corresponding theoretical PRI (Population Reference Intake) value for adult men. The median intakes of potassium, calcium, zinc, vitamins B2 and niacin were lower than PRI value but the mean difference was not significant. The mean intake of vitamin B1 was significantly lower than the PRI. There is no PRI to assess the vitamin $\mathrm{D}$ intakes; however, the mean vitamin $\mathrm{D}$ intake in our sample was significantly $(P<0.001)$ lower than in the French male general population ${ }^{28}$. Although higher than the PRI, the mean intake of vitamin $\mathrm{C}$ was also significantly $(P<0.001)$ lower than in the general population $^{28}$. There was a positive and significant correlation between ethanol intake and the intake of some nutrients, but this was restricted to vitamins present in beer (B2, B6 and niacin) and minerals found in red wine (copper, magnesium, iron, potassium).

\section{BMI distribution and correlation with otber vari- ables (Table 3)}

The mean BMI of the subjects was $23.8 \mathrm{~kg} / \mathrm{m}^{2}(\mathrm{SD}=3.9)$. BMI increased with age $(r=0.18, P=0.088)$. Drinkers had a significantly lower BMI than non-drinkers (23.0 $(\mathrm{SD}=3.6)$ vs. $\left.24.9(\mathrm{SD}=4.0) \mathrm{kg} / \mathrm{m}^{2}, P=0.018\right)$. The mean Z-score of the total sample was $-0.31(\mathrm{SD}=1.30)$, slightly underweight compared to the reference population of French males of the same age $(P=0.082)$. There was a significant positive association between BMI and non-alcoholic energy intake $(r=0.27, P=0.008)$ but not between BMI and total energy intake, or between BMI and alcohol intake. Four percent of the subjects were obese $(\mathrm{BMI}>30)$ and $7.3 \%$ were wasted $(\mathrm{BMI}<18.5)$. The seven subjects who were wasted were older than non-wasted subjects $(51.3(\mathrm{SD}=8.4)$ vs. $42.4(\mathrm{SD}=12.4)$ years, $P=0.065)$, all were smokers, six had been homeless for more than 18 months and five were drinkers. The mean intake of ethanol was not significantly different in the wasted sub-group than in the rest of the sample. Non-alcoholic energy intake was very low in the wasted sub-group (1422 (SD = 744) vs. $2074(\mathrm{SD}=750)$ kcal, $P=0.029$ ), as were the intakes of most nutrients.

\section{Nutrient intake according to the origin of foods or drinks (Table 4)}

Dietary intake came mainly from food provided by charitable organisations. The shelter provided $61.6 \%$ of non-alcoholic energy and the other charitable organisations provided 18\%. Although gifts (food given by individuals, generally in the street) and purchases represent $7 \%$ and $27 \%$ of total energy, respectively, they accounted for only $5.4 \%$ and $15 \%$ of the non-alcoholic energy intake, because of the great proportion of alcoholic drinks in the items given and purchased: $32 \%$

Table 3 Percentages of subjects in four grades BMI

\begin{tabular}{lcccc}
\hline & $\begin{array}{c}\text { Obesity } \\
(\mathrm{BMI}>30)\end{array}$ & $\begin{array}{c}\text { Over-weight } \\
(25<\mathrm{BMI}<30)\end{array}$ & $\begin{array}{c}\text { Ideal-weight } \\
(18.5<\mathrm{BMI}<25)\end{array}$ & $\begin{array}{c}\text { Under-weight } \\
(\mathrm{BMI}<18.5)\end{array}$ \\
\hline Homeless & 4.2 & 30.2 & 58.3 & 7.3 \\
French men (20-87 years, 1991) & 6.2 & 33 & 59.1 & 1.7 \\
\hline
\end{tabular}


Table 4 Nutritional density of the rations eaten in the shelter and purchased outside (after exclusion of alcoholic drinks)

\begin{tabular}{lcc}
\hline Nutrient & Shelter ration & Purchased ration \\
\hline Proteins $(\mathrm{g} / 1000 \mathrm{kcal})$ & $43.0(12.2)^{\star}$ & $31.1(15.8)$ \\
Fat $(\mathrm{g} / 1000 \mathrm{kcal})$ & $37.7(10.2)^{\star}$ & $31.9(16.0)$ \\
Carbohydrates $(\mathrm{g} / 1000 \mathrm{kcal})$ & $122(26)^{\star \star}$ & $147(46)$ \\
Potassium $(\mathrm{mg} / 1000 \mathrm{kcal})$ & $1301(418)$ & $1377(905)$ \\
Calcium $(\mathrm{mg} / 1000 \mathrm{kcal})$ & $332(137)$ & $377(388)$ \\
Phosphorus $(\mathrm{mg} / 1000 \mathrm{kcal})$ & $540(116)^{\star}$ & $463(229)$ \\
Iron $(\mathrm{mg} / 1000 \mathrm{kcal})$ & $5.70(1.32)^{\star}$ & $4.15(2.12)$ \\
Magnesium $(\mathrm{mg} / 1000 \mathrm{kcal})$ & $119(23)^{\star \star}$ & $271(554)$ \\
Copper $(\mathrm{mg} / 1000 \mathrm{kcal})$ & $0.60(0.13)^{\star}$ & $0.48(0.30)$ \\
Zinc $(\mathrm{mg} / 1000 \mathrm{kcal})$ & $4.73(1.36)^{\star}$ & $2.99(1.84)$ \\
Vitamin B1 $(\mathrm{mg} / 1000 \mathrm{kcal})$ & $0.41(0.12)$ & $0.48(0.38)$ \\
Vitamin B2 $(\mathrm{mg} / 1000 \mathrm{kcal})$ & $0.53(0.17)^{\star \star}$ & $0.65(0.41)$ \\
Niacin $(\mathrm{mg} / 1000 \mathrm{kcal})$ & $8.4(3.8)$ & $9.6(7.7)$ \\
Vitamin B6 $(\mathrm{mg} / 1000 \mathrm{kcal})$ & $0.84(0.25)^{\star}$ & $0.61(0.55)$ \\
Folate $(\mu \mathrm{g} / 1000 \mathrm{kcal})$ & $105(47)$ & $83(74)$ \\
Vitamin B12 $(\mu \mathrm{g} / 1000 \mathrm{kcal})$ & $1.54(0.72)$ & $2.14(3.60)$ \\
Vitamin A $(\mu \mathrm{gE} / 1000 \mathrm{kcal})$ & $408(365)$ & $483(1022)$ \\
Vitamin C $(\mathrm{mg} / 1000 \mathrm{kcal})$ & $29.4(20.0)$ & $32.0(61.9)$ \\
Vitamin D $(\mu \mathrm{g} / 1000 \mathrm{kcal})$ & $0.62(1.56)$ & $0.66(1.54)$ \\
\hline
\end{tabular}

* Significantly higher than the corresponding purchased value $(P<0.01)$; ** significantly lower than the corresponding purchased value $(P<0.01)$.

of the energy from given foods and $45 \%$ of energy of purchased food were provided by alcohol. Fifty-two individuals had purchased some food during the last $48 \mathrm{~h}$. To assess the possible nutritional complementarity of the rations eaten in the shelter with those purchased outside by these 52 subjects, we compared the nutritional densities of the two type of rations (after exclusion of alcoholic drinks). The ration eaten in the shelter provided more proteins and lipids and less carbohydrates than the ration purchased outside (Table 4). For most micronutrients, the nutritional density of the shelter ration was not significantly greater than the density of the purchased foods.

\section{Discussion}

This first study of the nutritional status and intake of homeless people living in Paris is consistent with findings from other countries: the nutritional status of homeless men, assessed by anthropometric measurements, is low compared to the general population ${ }^{9-12}$, and their ethanol intake is high ${ }^{29-31}$. The present study also suggests that non-alcoholic energy intake is low in this population and that insufficient intake of some nutrients may occur.

This study has limitations mainly because our sample may not be fully representative of the homeless population in Paris. Interviews were done before $22: 30 \mathrm{~h}$, excluding people eating and drinking outside the shelter and those brought late at night to the shelter by Samu Social minibuses. Some individuals may have gone to bed without eating and may have been missed by our study. About $10 \%$ of subjects refused being interviewed. For all these reasons, a selection bias is difficult to rule out. Yet, these biases tend to select individuals who are less at risk of nutritional inadequacy than the general homeless population. Hence, we believe that these potential biases do not invalidate the main conclusion of our study, namely that there are important dietary inadequacies among the homeless people in Paris. Actually, these biases may have lead to an underestimation of the observed inadequacies.

According to recent estimates, there are between 7200 and 7800 homeless adults using charity services in Paris every day ${ }^{8}$. Although we cannot guarantee that our sample selection is representative, the mean age and time of homelessness were consistent with values published in the annual report of the Samu Social ${ }^{14}$.

The proportion of homeless men having an 'ideal' $\mathrm{BMI}^{32}$ was greater in our sample than in the French reference population. However, a Z-score analysis showed that the BMI distribution was shifted towards low values, and the percentage of wasted persons was four times higher than in the reference population. Although never estimated, a high level of energy expenditure is conceivably associated with homelessness because of increased physical activity (walking) and cold exposure. Wasting in this population might also be explained by chronic diseases common in homeless people such as AIDS, tuberculosis, alcohol-related diseases, drug abuse or severe depression ${ }^{3}$. In our sample, drinkers had a significantly lower BMI than non-drinkers, which is in agreement with previous findings, sometimes in association with a liver disease ${ }^{33}$ and sometimes in isolation $^{34}$, especially in indigent or homeless alcoholics $^{35}$. In addition, the BMI was correlated with energy derived from food, suggesting that insufficient intake may contribute to the increased prevalence of underweight and wasting in this population. As previously shown in a large representative survey ${ }^{36}$, non-alcoholic energy was inversely correlated with ethanol intake, suggesting that the lower BMI of drinkers might be related to their low nutritional intakes. The seven men who were wasted had significantly lower mean non-alcoholic energy intake than the rest of the sample. Furthermore, they were older and may therefore have had a longer history of homelessness and/or alcoholism, which may also have had a detrimental effect on their nutritional status.

The low energy intake from food observed in our sample was associated with a low intake of most minerals and vitamins. The median intakes of potassium, calcium, zinc, vitamins B1, B2 and niacin were lower than the nutritional recommendations for adult men. Compared with the general population, intakes of vitamins $C$ and $D$ intakes were also $\operatorname{low}^{28}$. The low intakes of calcium and vitamin $\mathrm{D}$, in conjunction with the lower BMI, the high rate of smoking and the high consumption of alcohol are of special concern, because of the independent implication of these factors as risk factors for osteoporotic fractures in men $^{37}$. There is some evidence that bone loss is higher in alcoholic men, even at relatively young 
age $\mathrm{e}^{38-40}$. Similarly, the low intakes of vitamin $\mathrm{C}$ deserve attention because both smoking ${ }^{41}$ and chronic alcoholism $^{42}$ induce oxidative stress, increasing the need for antioxidant nutrients.

An important finding of the present study is that the intakes of most of the vitamins $\mathrm{B}$ were insufficient. Notably, the mean daily intake of vitamin B1 was significantly lower than the PRI. In addition, although higher than the PRI, the mean and median intakes of folate were lower than $350 \mu \mathrm{g} /$ day, the quantity known to prevent an increase in plasma homocysteine levels, a risk factor for cardiovascular diseases in the general adult population $^{43}$. Low dietary intakes of thiamine have been previously reported in homeless men living in Australia ${ }^{29}$ and were associated with a high prevalence of biochemical and clinical features of thiamine deficiency, WernickeKorsakoff syndrome particularly ${ }^{44}$. In fact, alcoholism is commonly associated with vitamin $\mathrm{B}$ deficiencies, inducing mental changes of various severity, depression and fatigue $^{45}$. Chronic ethanol intake also interferes with folate metabolism, impairing the safe disposal of homocysteine $^{46}$. Multivitamin B supplementation is routinely performed in the treatment of alcoholism and alcoholrelated diseases, and the fortification of alcoholic drinks with vitamin B1 has been proposed ${ }^{47}$.

Previous studies have already mentioned that nutrient deficiencies are likely to be prevalent in homeless men, as shown by low biological indicators for some important vitamins such as ascorbate (plasma levels), folate (plasma and erythrocyte levels) and thiamine ${ }^{9,44}$ (red-cell transketolase activity) and by low nutrient intakes ${ }^{11,31}$, notably low calcium intakes ${ }^{10,12}$. However, the health impact of this situation might be greater in France, where common foods are never fortified, than in countries like Australia or the United States, where the use of vitamin and mineral supplements or fortified foods are common, even among homeless populations ${ }^{44,48}$. The low vitamin $\mathrm{B}$ intakes and the high alcohol consumption found in our study are consistent with the high prevalence of psychiatric diseases reported in the population of homeless living in Paris ${ }^{49}$. The low vitamin C intake is also consistent with the report of sporadic scurvy cases in indigent alcoholics living in the Paris area ${ }^{50}$. The low calcium and vitamin D intakes might results in an increased incidence of bone fracture, but, to our knowledge, this has never been documented among the homeless.

Our study subjects were interviewed while 'housed' in the shelter. Dinner and breakfast were freely provided and alcohol consumption was forbidden. Food intakes might therefore have been overestimated and alcohol intakes underestimated compared to times of rough sleeping, in squats or streets or even in hotels. It has been shown in Boston that nutrient intakes were lower in homeless families placed in hotels by social services than in those who lived in shelter that provided food support and standard kitchen facilities ${ }^{51}$. Despite this probable selection bias in our study, we found low non-alcoholic energy and nutrient intakes and high ethanol intakes, suggesting that the actual situation of homeless nutrition might be worse than indicated by the present data.

The diets supplied by the shelter and other charitable organisations represented approximately $80 \%$ of the nonalcoholic energy intake during the days the men were accommodated. In addition, more than half of the subjects reported purchasing foods outside. For nutrients of the greatest concern, such as calcium, folate, niacin, vitamins $\mathrm{B} 1, \mathrm{C}$ and $\mathrm{D}$, the shelter meals did not provide sufficient amounts to balance the purchased ration. The need to add fresh products, in particular dairy products, to emergency food supplies has been reported in other countries $^{52,53}$. Direct prevention of vitamin $\mathrm{C}$ and folate deficiencies through increased utilisation of fruits, fruit juices, and vegetables should be recommended. Similarly, increasing cheese portions or introducing skimmed dried milk during cooking should be attempted to prevent calcium deficiencies. Foods naturally dense in niacin, vitamins B1 or D (yeast, wheat germ, liver, nuts, canned fish) are not commonly consumed in France in large quantities. For these nutrients, other possibilities, such as providing micronutrient supplements or fortified foods, should therefore be considered. Experience with vitamin B1 flour fortification in Australia suggests that this may have a major impact on the prevalence of alcohol-related diseases, in particular Wernicke-Korsakoff syndrome ${ }^{54}$.

\section{Acknowledgements}

The authors wish to thank the Association des Cités du Secours Catholique and the team of the night shelter of 17 Bd Ney, 75018 Paris, for their help, and in particular H. Lambertin, H. Dupuy, M. Prades, M. Aissaoui, O. Béal and P. Felin.

\section{References}

1 Shaw M, Dorling D. Mortality among street youth in the UK [letter]. Lancet 1998; 352: 743.

2 Barrow SM, Herman DB, Córdova P, Struening EL. Mortality among homeless shelter residents in New York City. Am J. Public Health 1999; 89: 529-34.

3 Hwang SW, Lebow JM, Bierer MF, O'Connell JJ, Orav EJ, Brennan TA. Risk factors for death in homeless adults in Boston. Arch. Intern. Med. 1998; 158: 1454-60.

4 Takano T, Nakamura K, Takeuchi S, Watanabe M. Disease patterns of the homeless in Tokyo. J. Urban Health 1999; 76: 73-84.

5 Shanks NJ. Medical morbidity of the homeless. J. Epidemiol. Community Health 1988; 42: 183-6.

6 Vredevoe DL, Brecht ML, Shuler P, Woo M. Risk factors for disease in a homeless population. Public Health Nurs. 1992; 9: 263-9.

7 Darnton-Hill I, Mandryk JA, Mock PA, Lewis J, Kerr CB. Sociodemographic and health factors in the well-being of homeless men in Sydney, Australia. Soc. Sci. Med. 1990; 31: $537-44$

8 Marpsat M, Firdion J. Les personnes sans domicile à Paris. In: 
Pumain D, Mattei M., eds. Données Urbaines. Paris: Anthropos, 1998: 217-30.

9 Laven GT, Brown KC. Nutritional status of men attending a soup kitchen: a pilot study. Am. J. Public Health 1985; 75 : $875-8$.

10 Wolgemuth JC, Myers-Williams C, Johnson P, Henseler C. Wasting malnutrition and inadequate nutrient intakes identified in a multiethnic homeless population. J. Am. Diet. Assoc. 1992; 92: 834-9.

11 Luder E, Boey E, Buchalter B, Martinez-Weber C. Assessment of the nutritional status of urban homeless adults. Public Health Rep. 1989; 104: 451-7.

12 Silliman K, Yamanoha MM, Morrissey AE. Evidence of nutritional risk in a population of homeless adults in rural northern California. J. Am Diet. Assoc. 1998; 98: 908-10.

13 Firdion J, Marpsat M, Mizrahi A. Vie et Santé des personnes sans domicile à Paris. Bulletin d'Information en Economie de la Santé (Credes) 1998; 13: 1-4.

14 Observatoire du Samu Social, De la grande précarité à la grande exclusion. Etude epidémiologique à parti des données (année 1998) du logiciel du numéro d'urgence pour les sans-abri (le 115). 1999.

15 Le Moullec N, Deheeger M, Preziosi P, Hercberg S. Validation du manuel photographique utilisé pour l'enquête alimentaire de l'étude SU.VI.MAX. Cah. Nutr. Diét 1996; 31: 158-64.

16 Favier J, Ireland-Ripert J, Toque C, Feinberg M.CIQUAL. Répertoire Général des Aliments. Table de composition. Paris: Lavoisier, Tec \& Doc, 2nd edition, 1995.

17 Lamand M, Tressol J, Ireland-Ripert J, Favier J, Feinberg M.CIQUAL. Répertoire Général des Aliments. Tome 4. Table de composition minérale. Paris: Lavoisier, Tec \& Doc, First edition, 1996.

18 Rolland-Cacheza MF, Cole TJ, Sempé M, Tichet J, Rossignol C, Charraud A. Body Mass Index variations: centiles from birth to 87 years. Eur. J. Clin. Nutr. 1991; 45: 13-21.

19 Cole TJ. The LMS method for constructing normalized growth standards. Eur. J. Clin. Nutr. 1990; 44: 45-60.

20 Scientific Committee for Food. Nutrient and energy intakes for the European Community. Luxembourg: Commission of the European Communities, 1993.

21 Dupin H, Abraham J, Giachetti I. Apports Nutritionnels Conseillés pour la population française. Paris: Lavoisier Tec \& Doc, 2nd edition, 1992.

22 Food and Nutrition Board. Recommended Dietary Allowances. Washington D.C.: National Academy Press, 10th edition, 1989.

23 Déontologie et bonnes pratiques en épidémiologie, recommandations de l'Association des épidémiologistes de langue française. ADELF Report, 1998.

24 Volatier J-L, Verger P. French food and nutrient intake data. Br. J. Nutr. 1999; 81: S57-9.

25 Hercberg S, Preziosi P, Galan P, Deheeger M, Dupin H. Apports nutritionnels d'un échantillon représentatif de la population du Val-de-Marne: II. Les apports en macronutriments [Dietary intake of a representative sample of the population of Val-de-Marne; II. Energetic nutrient intakes]. Rev. Epidémiol. Santé. Publique 1991; 39: 233-44.

26 Galan P, Lafond J, Arnaud J, Preziosi P, Durlach V, Duport N, Valeix P, Bouzid D, Favier A, Hercberg S. Apports alimentaires et statut biologique en magnésium dans la population adulte en France. Cah. Nutr. Diet. 1999; 32: 88-93.

27 Naveau S, Borotto E, Giraud V, Bardou M, Aubert A, Lazizi Y, Capron F, Poynard T, Chaput JC. Descriptive epidemiology of patients with alcoholic liver disease hospitalized in a hepato-gastroenterology service. Gastroenterol. Clin. Biol. 1999; 23: 544-51.

28 Guilland JC, Boggio V, Moreau D, Klepping J. Evaluation de l'apport alimentaire vitaminique en Bourgagne (France) [Evaluation of dietary vitamin intake in Burgundy (France)]. Ann. Nutr. Metab. 1986; 30: 21-46.
29 Darnton-Hill I, Ash S. Dietary and alcohol intake patterns of a sample of homeless men in Sydney, Australia. J. Hum. Nutr. Diet. 1988; 1: 397-408.

30 Fichter M, Quadflieg N, Greifenhagen A, Koniarczyk M, Wölz J. Alcoholism among homeless men in Munich, Germany. Eur. Psychiatry 1997; 12: 64-74.

31 Rushton C, Wheeler E. The dietary intake of homeless males sleeping rough in Central London. J. Hum. Nutr. Diet. 1993; 6: 443-56.

32 WHO. Physical status: the use and interpretation of anthropometry. Report of a WHO expert committee. Technical report Series no 854. Geneva: World Health Organization, 1999.

33 Addolorato G, Capristo E, Greco AV, Stefanini GF, Gasbarrini G. The influence of chronic alcohol abuse on body weight and energy metabolism: is excess ethanol consumption a risk factor for obesity or malnutrition? J. Intern. Med. 1998; 244: 387-95.

34 Gloria L, Cravo M, Camilo ME, Resende M, Cardoso JN, Oliveira AG, Leitão CN, Mira FC. Nutritional deficiencies in chronic alcoholics: relation to dietary intake and alcohol consumption. Am. J. Gastroenterol. 1997; 92: 485-9.

35 Goldsmith RH, Iber FL, Miller PA. Nutritional status of alcoholics of different socioeconomic class. J. Am Coll. Nutr. 1983; 2: 215-20.

36 Gruchow HW, Sobocinski KA, Barboriak JJ, Scheller JG. Alcohol consumption, nutrient intake and relative body weight among US adults. Am. J. Clin. Nutr. 1985; 42: 28995.

37 Kanis J, Johnell O, Gullberg B, Allander E, Elffors L, Ranstam J, Dequeker J, Dilsen G, Gennari C, Vaz AL., et al. Risk factors for hip fracture in men from southern Europe: the MEDOS study. Mediterranean Osteoporosis Study. Osteoporos. Int. 1999; 9: 45-54.

38 Spencer H, Rubio N, Rubio E, Indreika M, Seitam A. Chronic alcoholism. Frequently overlooked cause of osteoporosis in men. Am J. Med. 1986; 80: 393-7.

39 de Vernejoul MC, Bielakoff J, Herve M, Gueris J, Hott M, Modrowski D, Kuntz D, Miravet L, Ryckewaert A. Evidence for defective osteoblastic function. A role for alcohol and tobacco consumption in osteoporosis in middle-aged men. Clin. Orthop. 1983; 179: 107-15.

40 Crilly RG, Delaquerrière RL. Current bone mass and body weight changes in alcoholic males. Calcif. Tissue Int. 1990; 46: $169-72$.

41 Cross CE, Halliwell B. Nutrition and human disease: how much extra vitamin C might smokers need? Lancet 1993; 341 1091.

42 Lecomte E, Herbeth B, Pirollet P, Chancerelle Y, Arnaud J, Musse N, Paille F, Siest G, Artur Y. Effect of alcohol consumption on blood antioxidant nutrients and oxidative stress indicators. Am. J. Clin. Nutr. 1994; 60: 255-61.

43 de Bree A, van Dusseldorp M, Brouwer IA, van Het $H$, Steegers TR. Folate intake in Europe: recommended, actual and desired intake. Eur. J. Clin. Nutr. 1997; 51: 643-60.

44 Darnton-Hill I, Truswell AS. Thiamin status of a sample of homeless clinic attenders in Sydney. Med. J. Aust. 1990; 152 $5-9$.

45 Cook CC, Hallwood PM, Thomson AD. B Vitamin deficiency and neuropsychiatric syndromes in alcohol misuse. Alcohol Alcohol 1998; 33: 317-36.

46 Cravo ML, Glória LM, Selhub J, Nadeau MR, Camilo ME, Resende MP, Cardoso JN, Leitão CN, Mira FC. Hyperhomocysteinemia in chronic alcoholism: correlation with folate, vitamin B-12, and vitamin B-6 status. Am J. Clin. Nutr. 1996; 63: 220-4.

47 Connelly L, Price J. Preventing the Wernicke-Korsakoff syndrome in Australia: cost-effectiveness of thiamin-supplementation alternatives. Aust. N. Z. J. Public Health 1996; 20: $181-7$. 
48 Taylor ML, Koblinsky SA. Dietary intake and growth status of young homeless children. J. Am. Diet. Assoc. 1993; 93: 464-6.

49 Lecomte T, Mizrahi A. Recours aux soins et morbidité des personnes sans domicile permanent en région parisienne [Recourse to care and morbidity of the homeless in the Paris district]. Bull. Acad. Natl. Med. 1997; 181: 1715-27.

50 Fain O, Thomas M. Le scorbut actuellement. Cah. Nutr. Diet. 1997; 32: 300-5.

51 Wiecha JL, Dwyer JT, Jacques PF, Rand WM. Nutritional and economic advantages for homeless families in shelters providing kitchen facilities and food. J. Am. Diet. Assoc. 1993; 93: 777-83.
52 Derrickson JP, Widodo MM, Jarosz LA. Providers of food to homeless and hungry people need more dairy, fruit, vegetable, and lean-meat items. J. Am. Diet. Assoc. 1994; 94: 445-6.

53 Jacobs SL, Gray DK, Kuhnlein HV. Nutrient intake of food bank users is related to frequency of food bank use, household size, smoking, education and country of birth. $J$. Nutr. 1999; 129: 883-9.

54 Harper CG, Sheedy DL, Lara AI, Garrick TM, Hilton JM, Raisanen J. Prevalence of Wernicke-Korsakoff syndrome in Australia: has thiamine fortification made a difference? Med. J. Aust. 1998; 168: 542-5. 